\title{
Multicultural Education of Students as an Important Part of Education
}

\author{
Izida I. Ishmuradova ${ }^{1} \&$ Alfiya M. Ishmuradova ${ }^{1}$ \\ ${ }^{1}$ Kazan Federal University, Russia \\ Correspondence: Izida I. Ishmuradova, Kazan Federal University, Russia. E-mail: IIIshmuradova@kpfu.ru
}

Received: July 17, 2019

Accepted: October 10, 2019

Online Published: October 28, 2019

doi:10.5430/ijhe.v8n7p111

URL: https://doi.org/10.5430/ijhe.v8n7p111

\begin{abstract}
This article is about the improvement of the cross-cultural interaction of students. It is dealt with some country studies projects. It is shown that country studies projects have a positive effect on the process of teaching students. The content of this article can be used to improve the process of teaching a foreign language. results showed that Multicultural competencies of the students are the component of the professional competencies. Country studies projects, namely: creative works and country studies educational festivals are the effective basis for the formation of multicultural competencies of students.
\end{abstract}

Keywords: cross-cultural interaction, multiculturalism, improvement, culture, higher educational universities

\section{Introduction}

One of the most important tasks of modern education is to introduce students to global values, to develop in children and adolescents the ability to communicate and interact with representatives of neighboring cultures and in the global space. The tendencies of modern society in social, cultural, economic and political terms led to the formation of a multicultural society. Multicultural society is an educational space in which students of different ethno-linguistic, religious and socio-economic affiliations live and study. In recent years, in domestic pedagogy, they have increasingly begun to talk about the importance of multicultural aspects in the school audience. Independently formed such a direction as a multicultural education. Teaching a foreign language and foreign language culture contributes to the formation of students' ability to communicate, coexist with people of different ethnic groups, forms a rich experience of socio-cultural communication, which is a solid base for students to become familiar with the global values of civilization. The transition to the information society requires full development of the personality, including its communication skills, facilitating its entry into the world community, allowing it to function successfully.

Multicultural education of students is an essential part of education, especially nowadays when we need to be what many people call "multiculturally competent."

The relevance of the study determined the current trends of globalization; international migrations; cross-cultural cooperation in the field of economy, politics, culture and education. At present, modern society is becoming more multicultural, at the same time leads to misunderstanding, conflict, and aggression in cross-cultural relations (Milrud, 2004).

The consequence of this is the tendency of the world community to develop in the framework of multiculturalism, the equality of all cultures, tolerant attitude to cultural diversity and cultural peculiarities of other nations (Ariyan, 2003).

Multicultural competencies are the abilities to understand another culture well enough to be able to communicate and work with people from that culture. We are all culturally competent in our own culture. Multicultural competencies are more than one culture. There are usually cultural norms within a society, but they can change and collaborate with other cultures. All members of the society must be competent to communicate with each other for an effective multicultural process. The teaching of a foreign language and foreign culture contributes to the formation of pupils ' ability to communicate, to coexist with people of different ethnic groups, creates rich experience of social and cultural communication, which is a solid basis for introducing students to global values of civilization. The transition to the information society requires full development of personality, including communication skills, to facilitate its entry into the global community to function in it successfully. The students should have knowledge of complete 
picture of the world, skills and abilities; implement the activities of the modern value orientations, principles of intercultural communication in the country, at the international level (Hamlet, 2002).

Therefore, the formation of multicultural competence of students by means of country studies projects are extremely important part of the learning process.

\section{Methods}

In universities, in the unified educational space for students of different cultural, national and social groups, sometimes there are cases of aggressiveness in the relationship and disrespect towards the national differences among students, so the relevance of the study stems from the fact that in their future professional activities of students should be prepared to solve these problems (Khaleeva, 1990).

Defining psychological characteristics of student age, it should be noted that at this age there is effective development of spiritual qualities. Therefore, the formation of a multicultural competence of students in the process of University education becomes relevant and can influence the formation of the moral relationship with the subjects of their future professional activities. It should be noted that there is insufficient depth study of the problem of multicultural competencies in interpersonal relations within a multinational student group in the process of higher education, as well as in the educational program of the University. As a result, caused the need for the formation of multicultural competencies of students in the process of learning foreign languages. The more global is the object on which it is possible to realize the goal of foreign language as means of intercultural communication (Passov, 2007; Deyhim \& Zeraatkish, 2016).

The problem of the multicultural competencies is the research subject of plenty of foreign and Russian scientists. The tendency of formation of tolerance in inter-ethnic relations in developed countries is solved by the formation of multicultural competencies. A number of scholars working in the field of multicultural education (Ariyan, 2003; Berulava \& Berulava, 2009; Hamlet, 2002; Milrud, 2004; Polat, 2000; Ribe \& Vidal, 1993; Sysoev, 2004) developed theoretical principles that reveal the conceptual approaches to the problem of forming of multicultural competencies.

An important area of the study is the way for peaceful interaction between different ethnic groups and creates an atmosphere of harmony, tolerance, respect, conflict resolution inter-ethnic level. In Russian education multiculturalism as competence is only beginning to be studied (Sysoev, 2004).

Today the formation of multicultural competencies of students is not completely disclosed. The purpose of this article is to study scientific and methodological foundations of multicultural competencies of students by means of country studies projects, to reveal their role and importance (Zimnyaya, 2002).

\section{Results and Discussions}

Multiculturalism is the main feature of modern society. Therefore multicultural competencies of students, we consider as an integral part of professional competencies, which should be carried out at all stages of the professional activity. There are many definitions of multicultural competencies as a concept; its components were defined, as well as structural components (Berulava \& Berulava, 2009; Jahani et al., 2016).

We define the multicultural competencies of the students as the ability of the individual to realize multicultural competences harmoniously, having a sum of multicultural knowledge and language skills, adequately and diplomatically establish the cultural interaction process, be tolerant to people of different nationalities in order to solve the professional tasks knowledgeably. In the structure of multicultural competencies of the students we distinguish four interrelated components: informational, communicative, verbal, ethical. Formation of multicultural competencies of students as one of the key professional competencies and is carried out throughout the whole period of study in higher educational institutions, including the country studies projects (Fried-Booth \& Project work, 2002).

The country studies projects are one of the basic subjects, in which the formation of multicultural competencies of the students is carried out effectively. Extremely effective is the use of new approaches to the study of the course. The method of projects is one of such methods. While studying of country studies the project method is used in the preparation of creative works as one of the most effective forms of individual scientific and research tasks during the accomplishment of students' self-reliant tasks. By the students the creative works were done during the first two academic years. The purpose of training is to expand and deepen students' knowledge of subjects while the accomplishment of self-reliant task. To date, scientific and methodical recommendations on the creation of creative works were developed, in which their purpose, objectives are defined, the types (country studies imagery, country studies routes, mini-reports, comprehensive country studies data) were developed, stages of preparation were offered, 
features of design and evaluation, public defense, ways of practical implementation of the results were disclosed. Creative works are the effective basis for the formation of multicultural competencies of students of international field. The best, what is performed by the students, is to reveal the topics of cultural and socio-cultural nature. During the implementation of such a project as creative work the most effectively the following components of multicultural competencies, as knowledge and informational and ethical and motivational are formed. Further development of accomplished projects is going on by several ways: participation in scientific conferences, as the material for term papers and dissertations writing, extensions and presentation of the themes on the country studies meetings, festivals, round tables, etc. The powerful country studies projects in extracurricular activities of students, who actively contribute to the formation of multicultural competencies, are the projects, which are related to the country studies educational clubs. During the working on projects of country studies two creative «English Speaking Clubs» were held at the KFU University: "Dialogue of Cultures: America" (May 13, 2017), "Dialogue of Cultures: Great Britain" (October 25,2017$)$ are actively promoted. The participants of each event are more than 50 people. In November, 2018 the conduction of the third club "Dialogue of cultures: Canada, Australia and New Zealand" is planned. The aim of the clubs is to introduce young people to the peculiarities of cultures, promote the formation of personality on the basis of tolerance and mutual respect to other cultures and peoples. The objectives of the clubs are: 1) to familiarize the participants with various aspects of cultural country studies features; 2) to promote the formation of personality on the principles of friendship and respect between peoples; 3) to develop the understanding of global interdependence of all countries and peoples; 4) to develop the communicative skills, promote the ability to communicate with people of different nationalities; 5) to develop the creative potential of the person, as well as skills that contribute to increase knowledge about the other cultures; 6) to promote a sense of beauty in the best achievements of world civilization. In the organization and conduction of the festival the students took an active part, especially students, who prepare the information booths, presentations, welcome guests, conduct the sessions, organize the workshops etc. The main sessions' moderators are those students and are ready to demonstrate their knowledge, skills and abilities in practice. On workshops and creative studios of the clubs event participants have the opportunity to get acquainted with the cultural diversity of the countries and peoples of the world in a practical context. To their conduction the culture-bearers, embassies, consulates, foreign guests and experts are usually involved. As the practical experience shows, in the organization and conduction of the educational clubs on the basis of voluntarism, usually $80-90 \%$ of students, who are studying or have studied the subject «Country Studies», take part. It should be noted that a number of students continue the club activities, even being the graduates. In general, we emphasize, that the participation in the country studies project club activities contributes primarily to the formation of strong communicative and ethical and motivational components of multicultural competencies. In addition, there is a possibility to strengthen and deepen the speech component, as well as knowledge and informational (Polat, 2000; Ribe \& Vidal, 1993).

Effective methods in the process of teaching foreign languages are dialogues, projects, Internet communication, role-plays, training and discussions that allow us to correlate them with the principles of multiculturalism, which provide an extension of the boundaries of the worldview of students; tolerant of interpersonal and intercultural relations; self-determination of their own culture; emotional stability to cultural differences; developing a sense of empathy; the creative development of students; develop a global thinking; liberation from stereotypes (Bimurzina, 2013; Kor et al., 2019).

When learning English, students acquire the following skills to ensure their self-education:

- ability to critically evaluate the information received;

- solve problems of a different nature;

- argumentatively argue and speculate;

- use modern information technologies;

- improve their activities,

- be ready to share their knowledge and experience with others;

- communicate at the level of speech and writing; work in a team,

- be communicative;

- adapt to different communication situations.

For example, a discussion of a read country-specific text implies its assessment, a reasoned proof of one or another point of view. Drawing up dialogues characteristic of students in different situations of the English-speaking 
environment allows them to develop such qualities as adaptability to the many situations of a multicultural environment, the ability to communicate with different interlocutors under various circumstances (for example, situations arising from foreign travel, international events, etc.

The conditions for self-education of schoolchildren are created by implementing a number of areas of multicultural education:

- English lessons, in which students become familiar with the facts of the culture of the countries of the target language, such as traditions, customs, and holidays, starting from elementary school.

For example, a lesson on the subject "National English, American, Russian, Tatar dishes" was held, for which students prepared mini-projects for themselves, and on Valentine's Day, students studied the information about its celebration in different countries of the world.

- elective courses,

For example, when studying an elective course COUNTRY students presented tourist guides to English-speaking countries of the world. Projects were carried out, which made it possible to use all the necessary literature, the Internet, and our own materials.

- integrated lessons,

- theater performances,

- creation of interactive benefits

- project activity is a very effective and popular method that allows students to work on a task in one team and successfully use all sorts of sources of self-education.

For example, in the framework of the topic SPORTS, students investigated the features of different kinds of sports that occurred in different countries of the world.

- teaching and research activities

- optional classes,

- out-of-class and out-of-school work, in the framework of which students are also happy to take part in English-language theater performances, being acquainted with the folklore and works of foreign writers. High school students take part in linguistic forums, for example, held by KFU.

- study of local history material,

For example, students independently prepared an English-language excursion around Kazan. The rest of the students were asked to tell about their hometown in the role-playing game, "I try myself as a volunteer".

- virtual tours of countries and cities,

- Internet projects,

- creative work,

For example, when studying the topic National currencies of the United Kingdom and the United States, fifth-graders independently studied and represented national currencies of other countries.

- distance and face-to-face contests and competitions.

In the course of implementation of these areas of multicultural education, self-education of English teachers is also provided, which is the basis of our successful work, without which it is impossible to imagine yourself in this profession.

The forms of practical application of the results of the work on self-education are the introduction of innovative educational technologies in the process of teaching English, streamlining the process of teaching and learning activities in the subject, improving the quality of teaching and the level of foreign language training.

\section{Conclusion}

The analysis of the above mentioned information allows us to formulate the following conclusions. Multicultural competencies of the students are the component of the professional competencies. Country studies projects, namely: creative works and country studies educational festivals are the effective basis for the formation of multicultural competencies of students. Multicultural competencies, as well as other types of professional competencies of students, are formed throughout the whole period of study in the higher educational institutions, and its' means and 
methods of formation can be improved and developed in general. Cross-cultural interaction of students can guarantee the peace and stability in the world if it gains the global scale and is supported by conscious individuals, world progressive society (Ishmuradova \& Ishmuradova, 2015; Ishmuradova \& Ishmuradova, 2017; Fitriani \& Suryadi, 2019).

\section{Acknowledgements}

The work is performed according to the Russian Government Program of Competitive Growth of Kazan Federal University.

\section{References}

Ariyan, M. A. (2003). Ways of Improving of Professional Competence of Teachers of a Foreign Language. ES, 1, 86.

Berulava, M. N. \& Berulava, G. A. (2009). Methodological basis for the development of student's personality in high school. Herald University of the Russian Academy of Education, 4.

Bimurzina, I. V. (2013). Russian as a foreign language in a professional context: Study manual. Vladivostok, Dalrybvtuz, 157.

Deyhim, T. \& Zeraatkish, Y. (2016). Investigate the trend of rural development in Gachsaran city with Morris method. UCT Journal of Management and Accounting Studies, 4(1), 23-28.

Fitriani, N. \& Suryadi, I. (2019). A Review study on online psycho-education for the bipolar disorder patient and their caregivers. Humanities \& Social Sciences Reviews, 6(2), 84-89. https://doi.org/10.18510/hssr.2018.6210

Fried-Booth, D. L. \& Project work, D. L. (2002). Fried-Booth. - Oxford: Oxford University Press, 98 p.

Ghadirzadeh, R., Hashtroudi, F. P. \& Shokri, O. (2012). Demotivating factors for English language learning among university students. J. Soc. Sci., 8, 189-195.

Hamlet, A. V. (2002). Determination Content and Core Competencies as the Nature of the New Approach to Designing of Educational Standards: the abstract.

Ishmuradova, A. M. \& Ishmuradova, I. I. (2015). Formation of the foreign language competence of the university students in the design activity. Socio-economic and technical assistance with the system: research, design, optimization, 1(64), 182-192.

Ishmuradova, I. I. \& Ishmuradova, A. M. (2017). Stochastic modeling of economic activity of costs on Innovation of the organization of the Republic of Tatarstan, in the formation of business processes. Revista Publicando, 12(1), 545-559.

Jahani, A., Rostami, V. \& Shabanzadeh, M. (2016). The Impact of management duty duration on the Operational Cycle duration of the Companies Listed in Tehran Stock Exchange. UCT Journal of Social Sciences and Humanities Research, 4(1), 15-24.

Khaleeva, I. I. (1990). Fundamentals of the Theory of Learning of Foreign Speech Understanding. Moscow: 19.

Kor, L., Teoh, S., Binti Mohamed, S. S. E. \& Singh, P. (2019). Learning to Make Sense of Fractions: Some Insights from the Malaysian Primary 4 Pupils. International Electronic Journal of Mathematics Education, 14(1), 169-182. https://doi.org/10.29333/iejme/3985

Milrud, R. P. (2004). Competence in language learning. P. R. Milrud// ES, 7, 30 - 36.

Passov, E. I. (2007). The Concept of Communicative Foreign Language Education: A Manual for Russian Studies. Moscow: 145.

Polat, E.S. (2000). Project-based foreign language lessons / E.S.Polat. Foreign languages at school, 3, 3-9.

Pussyrmanov, N., Rystina, I., Bulegenova, B., Askeyeva, G. \& Gabdulina, B. (2018). President Nursultan Nazarbayevs program article "The course towards future: Modernization of public consciousness"-ideology, value and political aspects. Opción, 34(85-2), 824-837.

Ribe, R. \& Vidal, N. (1993). Project Work. Step by Step. / R.Ribe, N.Vidal. - Oxford: Heinemann, 456.

Sysoev, P. V. (2004). Cultural self-determination of students in terms of language multicultural education. ES, 4, 14-20.

Zimnyaya, I. A. (2002). Educational Psychology. Moscow, Logos. 